\title{
Potential distribution and new records of Trinomys species (Rodentia: Echimyidae) in the state of Rio de Janeiro
}

\author{
Nina Attias 1, 4; Daniel S. L. Raíces 1; Flávia S. Pessoa '; Hermano Albuquerque 1; \\ Tássia Jordão-Nogueira ${ }^{2}$; Thiago C. Modesto ${ }^{1} \&$ Helena de G. Bergallo ${ }^{1}$
}

\author{
${ }^{1}$ Laboratório de Ecologia de Pequenos Mamíferos, Departamento de Ecologia, Instituto de Biologia Roberto Alcântara, \\ Universidade do Estado do Rio de Janeiro. Rua São Francisco Xavier 524, Maracanã, 20559-900 Rio de Janeiro, Rio de \\ Janeiro, Brasil. \\ 2 Programa de Pós-graduação em Ecologia, Universidade Federal do Rio de Janeiro. Ilha do Fundão, Cidade Universitária, \\ 21941-901, Rio de Janeiro, Rio de Janeiro, Brasil. \\ ${ }^{4}$ Corresponding author. E-mail: ninaattias@yahoo.com.br
}

\begin{abstract}
The spiny rats of the genus Trinomys Thomas, 1921 have a broad distribution in the Atlantic Forests of southeastern Brazil. However, some species are known only from their type locality and adjacent areas. In our study, nine areas in the state of Rio de Janeiro were surveyed and three species of the genus were captured - Trinomys dimidiatus (Günther, 1877), T. setosus (Desmarest, 1817) and T. gratiosus bonafidei (Moojen, 1948). We extended the distribution of $T$. gratiosus bonafidei in $100 \mathrm{~km}$, in a straight line to the northwest, and into an area of Semidecidual Seasonal Forest. We captured $T$. setosus, which had not been previously recorded in the state, in the municipality of Cambuci, extending its distribution $150 \mathrm{~km}$, in a straight line to the east of its closest record, in Juiz de Fora, state of Minas Gerais. The state of Rio de Janeiro has now six recognized species of Trinomys, however none of them were collected above $1300 \mathrm{~m}$ of altitude. We used occurrence points provided by our inventories data and from the literature to model the potential distribution of Trinomys species. We used climatic, topographic and phytogeographic variables to prepare the potential distribution maps. The algorithm used for modeling was provided by the software Maxent, version 3.2.1. Although species boundaries within Trinomys in Rio de Janeiro State are not yet clear, their distributions seem to be parapatric, except for $T$. iheringi and $T$. dimidiatus.
\end{abstract}

KEY WORDS. Ecoregions; climatic variables; distribution models; altitude.

Spiny rats of the genus Trinomys Thomas, 1921 (Echimyidae) have a broad distribution, with species being recorded across six Brazilian states (LARA et al. 2002). These species are found mostly in Atlantic Forest areas of eastern Brazil, at altitudes ranging from sea level to 1300 meters (Moojen 1948, PessôA \& ReIs 1996, BonviCINo et al. 1997, Eisenberg \& Redford 1999, Lara \& Patton 2000, Lara et al. 2002, GeIse et al. 2004). Aspects of their distribution, species limits and taxonomy are poorly known, with some species known only from their type locality and surroundings - e.g. Trinomys gratiosus bonafidei (Moojen, 1948), Trinomys yonenagae (Rocha, 1995) and Trinomys moojeni (Pessôa, Oliveira \& Reis, 1992) - (PessôA et al. 1993, Lara \& PatTon 2000, Lara et al. 2002, CorrêA et al. 2005).

These rodents have nocturnal habits, using fallen and hollow logs, and holes in the ground as shelters during the day. They are solitary, terrestrial animals, with a diet based on seeds, fruits, fungi, a few leaves and insects (Emmons \& FeER 1997). The dorsal pelage is characterized by a superficial set of long and stiff guard hairs, with reddish brown coloration, that may be spinescent or soft, and the ventral hair is always whitish (EISENBERg \& REDFord 1999).

Five species of the genus have been recorded in the state of Rio de Janeiro: Trinomys dimidiatus (Günther, 1877), T. iheringi (Thomas, 1911), T. gratiosus bonafidei, T. eliasi (Pessôa \& Reis, 1993) (Lara \& Patton 2000, Rocha et al. 2004) and, more recently, T. panema (Moojen, 1948) (IACK-Ximenes pers comm.). Trinomys dimidiatus has a distribution restricted to the state of Rio de Janeiro and the northern coast of the state of São Paulo, being found in sympatry with $T$. iheringi, which has a distribution from southern São Paulo to southern Rio de Janeiro (PEssôA \& Reis 1993, Pereira et al. 2001). Trinomys eliasi is endemic to the state of Rio de Janeiro, being found in the Restinga da Barra de Maricá, municipality of Maricá, in the Restinga de Jurubatiba National Park, municipality of Carapebus, and in the Poço das Antas Biological Reserve, municipality of Silva Jardim, state of Rio de Janeiro (Pessôa \& Reis 1993, Brito \& Figueiredo 2003, Bergallo et al. 2004, Rocha et al. 2005). Trinomys gratiosus bonafidei is also endemic to the state, and is only known to 
occur at the type locality in Fazenda Boa Fé, municipality of Teresópolis, and surroundings (Moojen 1948, PessôA \& ReIs 1996, Oliveira \& Bonvicino 2006). Trinomys panema is known from the states of Espírito Santo, Minas Gerais and Rio de Janeiro. In Rio de Janeiro, this species is known only from the Itatiaia National Park (IACK-XIMENES pers. comm.).

This study reports additional sites of occurrence for species of Trinomys in Rio de Janeiro and estimates their potential range using methods of distribution modeling.

\section{MATERIAL AND METHODS}

We carried out small mammal inventories in nine areas in the state of Rio de Janeiro from 2004 to 2006.

The captures in each area were done using 126 Sherman and Tomahawk live traps, set in three distinct lines. The traps, placed on the ground (90), were set $40 \mathrm{~m}$ apart from each other. Traps placed on trees (36) were set $100 \mathrm{~m}$ apart and at a minimum height of $2.5 \mathrm{~m}$. They were opened during six consecutive nights with a total effort of 756 traps/night. Thirty buckets of 40 liters set in three distinct tracks were utilized as pitfalls, for a total of 180 buckets/night.

All the specimens were identified by a combination of characteristics of the cranium, teeth, hair, baculum structure, and external body measures, and classified within the nomenclature considered valid in LARA \& PATTON (2000).

The state of Rio de Janeiro $\left(20^{\circ} 45^{\prime} 45^{\prime \prime}\right.$ to $23^{\circ} 22^{\prime} 10^{\prime \prime} \mathrm{S}$, $40^{\circ} 57^{\prime} 20^{\prime \prime}$ to $44^{\circ} 53^{\prime} 20^{\prime \prime} \mathrm{W}$ ) has an area of $43.864,3 \mathrm{~km}^{2}$ (Fidalgo et. al. 2007) and was originally covered by Atlantic Forest. However, today only $20.33 \%$ of the forest's original extension remains intact (FundaÇão SOS Mata ATLÂNTICA 2002), being distributed in several fragments of different sizes and conservation stages.

Nine localities were chosen for inventory (Fig. 1) based on absence of information on the area, accessibility, region of the state (we tried to survey all of the state regions - sensu SARAÇA et al. 2007), size and number of forest fragments in the area. The areas selected were: 1) Paraíso State Ecological Station (EEEP), 2) Santo Antônio da Aliança Farm (FSAA), 3) Rio das Pedras Ecological Reserve (RERP), 4) Desengano State Park (PED), 5) Vale da Pedra Branca Farm (FVPB), 6) Esmeralda Farm (FE), 7) Guapiaçú Ecological Reserve (REGUA), 8) Marimbondo Farm $(\mathrm{FM}), 9)$ Morro São João (MSJ). Characterization of each area is available in the appendix 1 . Climate data were obtained in Hijmans et al. (2005) and vegetation characterization was conducted based on URURAHY et al. (1983).

To model the potential distribution of Trinomys spp., we used a total of 97 occurrence points provided by our inventories and from literature (Bittencourt 2003, Pereira et al. 2001, Cunha \& RajÃo 2007, Olifiers et al. 2007, VAZ et. al. 2007, IACKXIMENEs pers. comm.). The number of points per species was 26 for T. dimidiatus, 7 for T. eliasi, 5 for T. gratiosus bonafidei, 15 for T. iheringi, 12 for T. setosus elegans, 16 for T. setosus setosus and 16 for T. panema.
We used 19 climatic, one topographic and one phytogeographic variables to assemble the potential distribution maps (Olson et al. 2001, Hijmans et al. 2005). The variables were Annual Mean Temperature (AMT), Mean Diurnal Range (MDR), Isothermality (ISO), Temperature Seasonality (TES), Maximum Temperature of Warmest Month (MTWM), Minimum Temperature of Coldest Month (MTCM), Annual Temperature Range (ATR), Mean Temperature of Wettest Quarter (MTWE), Mean Temperature of Driest Quarter (MTDQ), Mean Temperature of Warmest Quarter (MTWA), Mean Temperature of Coldest Quarter (MTCO), Annual Precipitation (ANP), Precipitation of Wettest Month (PWM), Precipitation of Driest Month (PDM), Precipitation Seasonality (PRS), Precipitation of Wettest Quarter (PWE), Precipitation of Driest Quarter (PDQ), Precipitation of Warmest Quarter (PWQ), Precipitation of Coldest Quarter (PCQ), altitude (Hijmans et al. 2005) (Appendix 2) and a layer of terrestrial ecoregions (Olson et al. 2001). All layers had the resolution of 30 arc-seconds (i.e. $\sim 1 \mathrm{~km}^{2}$ ).

For $T$. dimidiatus, we used $75 \%$ of the occurrence points to generate the potential distribution model; $25 \%$ were used for model validation (Philuips et al. 2006). We applied the method suggested by PEARSON et al. (2007) to predict the species distribution with few records of occurrence (i.e. <25). We used this method for all species, but $T$. dimidiatus. This method uses a statistical approach based on jackknife techniques for evaluation of the generated models. For species with $\mathrm{n}$ occurrence points, $\mathrm{n}$ models are constructed using $\mathrm{n}-1$ locations. Each generated model is tested for its ability to predict the deleted location. During the model validation, when a point was removed, it was verified if there was another near point, in a distance up to $10 \mathrm{~km}$. In this case, the point was removed from the model (PEARSON et al. 2007). The results of this procedure were used in the software pValueCompute (PEARSON et al. 2007) to assess whether the model with all localities was able to predict the potential distribution better than a random prediction.

The algorithm used for modeling was provided by the software Maxent version 3.2.1 (http://www.cs.princeton.edu/ schapire/maxent/, accessed in May 2008). The software provides a continuous probability result of occurrence that ranges from 0 to 1 (Phillips \& Dudik 2008). We used 10,000 points chosen randomly to characterize the entire area where the prediction was made (Phillips \& DUdik 2008). We used the default convergence threshold (i.e. $10^{-5}$ ) and the maximum number of interactions (i.e. 500).

The software provides a jackknife test to assess which variables were the most important in modeling the potential distribution. For this, the software generates a model using only one variable at a time. For each variable removed, another model is generated with the remaining variables. The results are then compared with the performance of the model created with all variables.

For jackknife validation approach we used two thresholds (PeArson et al. 2007). First, we chose the lowest presence 


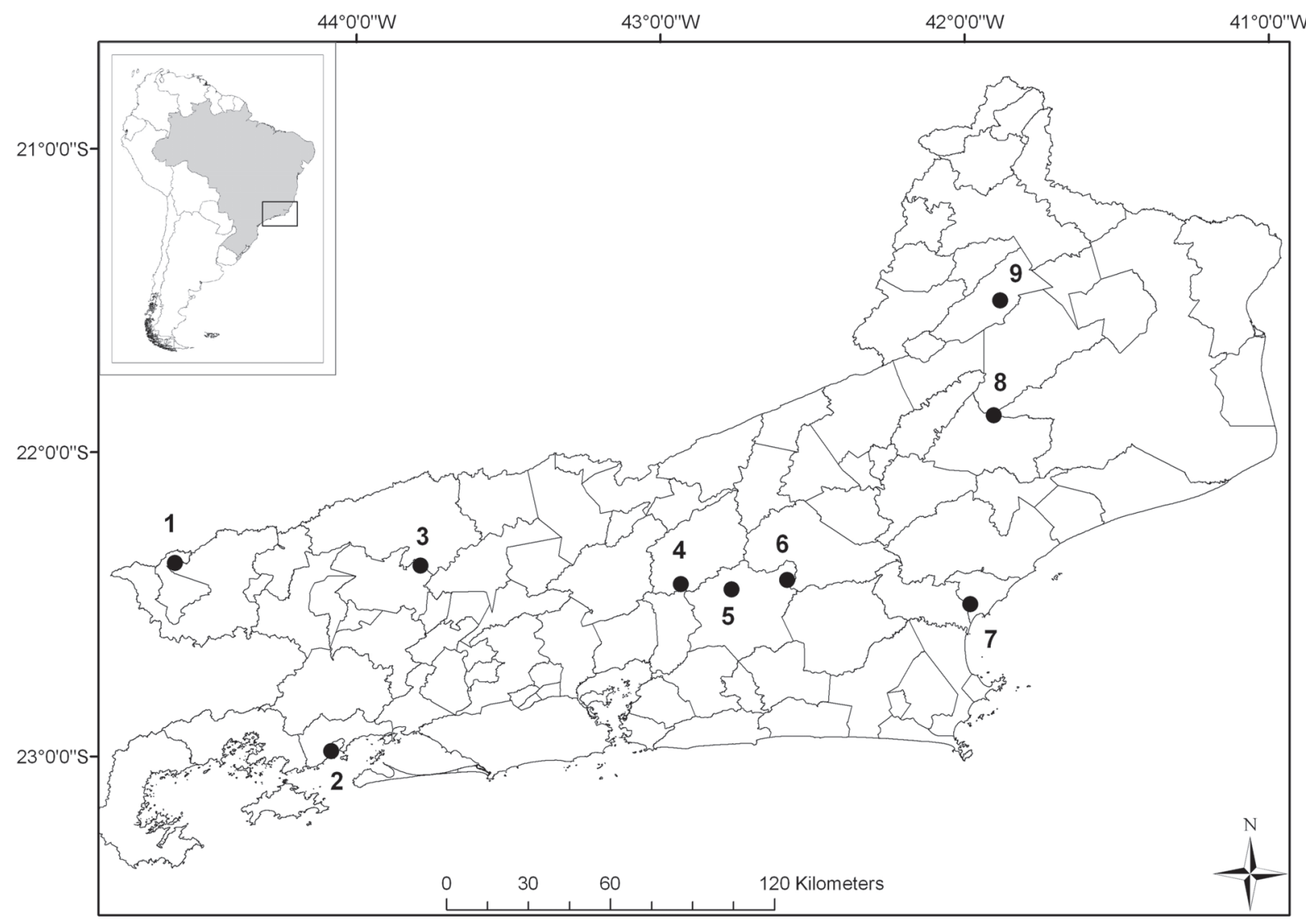

Figure 1. Map of the state of Rio de Janeiro showing the nine localities sampled in this study. Legend: 1) Marimbondo Farm, 2) Rio das Pedras Ecological Reserve, 3) Santo Antônio da Aliança Farm, 4) Paraíso State Ecological Station, 5) Guapiaçú Ecological Reserve, 6) Vale da Pedra Branca Farm, 7) Morro São João, 8) Desengano State Park, 9) Esmeralda Farm.

threshold (LPT) able to include in predicting distribution all points used in training model (i.e. the model with all $n$ points). This can be interpreted as an identification of pixels with similar conditions to those found in the species record localities. The second threshold applied was chosen aiming to withdraw $10 \%$ of the lowest prediction values (T10). This second approach is less conservative and identifies a larger portion of the area. We made the final maps of potential distribution using the software ArcGis 9.2. We plotted only the LPT maps, due to its conservative characteristics.

\section{RESULTS}

We captured three species of Trinomys in the studied areas, namely T. dimidiatus, T. gratiosus bonafidei, and T. setosus. All of them were captured in traps placed in the ground, in both live traps and/or pitfall traps. Specimens of Trinomys were not captured in three localities - MSJ, FM and REGUA. The data on the collected specimens can be viewed in table I.

The potential distribution maps generated with the T10 threshold showed a high success rate and were statistically sig- nificant (Tab. II). The results for the maps using the LPT threshold were also validated. However the species T. eliasi (0.428) and T. gratiosus bonafidei (0.200) showed low success rates with LPT threshold. Trinomys dimidiatus (1.000), T. iheringi (0.867), T. panema (0.938) and T. setosus setosus (0.938) showed equal success rates for both LPT and L10 thresholds (Tab. II).

Except for T. eliasi, the ecoregion was the variable with highest gain when used in isolation and the variable that most decreases the gain when omitted (Tab. II). Only for Trinomys eliasi, altitude had a higher effect than ecoregion. For T. gratiosus bonafidei, PWQ was the highest gain variable (Tab. II).

All species occurred in Alto Paraná Atlantic Forest, except $T$. setosus subspecies and T. dimidiatus (Tab. III). Trinomys eliasi also occurred in Atlantic Coastal Restingas, T. g. bonafidei in Campos Rupestres Montane Savanna and T. iheringi in Southern Atlantic Mangroves. Trinomys dimidiatus is restricted to Serra do Mar Coastal Forest and Southern Atlantic Mangroves ecoregions. On the other hand, Trinomys panema occurred in five of the nine ecoregions reported for the studied species (Tab. III and Fig. 2). 
Table I. Specimens of Trinomys captured in the studied areas (Locality), museum number, number of individuals captured ( $\mathrm{N})$, mean and standard deviation of body weight (W) and of the measurements: head and body (HB), tail (TA), head (HE), ear (E), hind foot with (HFU) and without nails (HF).

\begin{tabular}{|c|c|c|c|c|c|c|c|c|c|c|}
\hline Species & Locality & $\begin{array}{c}\text { Museum } \\
\text { number }\end{array}$ & $\mathrm{N}$ & W & $\mathrm{HB}$ & TA & $\mathrm{HE}$ & $\mathrm{E}$ & $\mathrm{HF}$ & HFU \\
\hline T. gr. bonafidei & FSAA & MN 70154 & 4 & $203.00 \pm 36.50$ & $16.50 \pm 4.36$ & $14.43 \pm 5.77$ & $5.37 \pm 0.81$ & $2.50 \pm 0.46$ & $4.57 \pm 0.15$ & $4.90 \pm 0.26$ \\
\hline T. dimidiatus & EEEP & $\begin{array}{l}\text { MN 70155, } \\
\text { MN } 70156\end{array}$ & 82 & $204.54 \pm 53.79$ & $19.02 \pm 2.15$ & $15.53 \pm 4.15$ & $5.57 \pm 0.64$ & $2.05 \pm 0.06$ & $4.26 \pm 0.45$ & $4.27 \pm 0.17$ \\
\hline T. dimidiatus & RERP & MN 70157 & 15 & $172.00 \pm 63.31$ & $19.22 \pm 2.83$ & $17.04 \pm 3.19$ & $5.36 \pm 0.66$ & $2.45 \pm 0.71$ & $4.31 \pm 0.33$ & $4.63 \pm 0.35$ \\
\hline T. dimidiatus & PED & $\begin{array}{l}\text { MN 70158, } \\
\text { MN } 70159\end{array}$ & 16 & $176.43 \pm 36.92$ & $17.39 \pm 2.97$ & $16.01 \pm 3.32$ & $5.15 \pm 0.46$ & $2.11 \pm 0.19$ & $4.17 \pm 0.22$ & $4.44 \pm 0.20$ \\
\hline T. dimidiatus & FVPB & MN 70160 & 3 & 220.00 & 20.70 & 16.00 & 4.50 & 2.80 & 4.40 & 4.7 \\
\hline T. setosus & $\mathrm{FE}$ & $\begin{array}{l}\text { MN 70161, } \\
\text { MN } 70162\end{array}$ & 11 & $198.43 \pm 77.14$ & $18.69 \pm 1.94$ & $18.40 \pm 3.66$ & $5.60 \pm 0.60$ & $2.37 \pm 0.32$ & $4.81 \pm 0.18$ & $5.23 \pm 0.14$ \\
\hline
\end{tabular}

Table II. Jackknife tests of distribution models for six Trinomys species. (LPT) Lowest presence threshold, (T10) withdrawing $10 \%$ of the lowest prediction values, (PWQ) Precipitation of Warmest Quarter.

\begin{tabular}{|c|c|c|c|c|c|c|c|}
\hline \multirow{2}{*}{ Species } & \multirow{2}{*}{$\begin{array}{l}\text { Locality } \\
\text { sample size }\end{array}$} & \multicolumn{2}{|c|}{ LPT } & \multicolumn{2}{|c|}{$\mathrm{T} 10$} & \multirow{2}{*}{$\begin{array}{l}\text { Highest gain } \\
\text { variable }\end{array}$} & \multirow{2}{*}{$\begin{array}{l}\text { Highest information } \\
\text { variable }\end{array}$} \\
\hline & & Success & $p$ value & Success & $p$ value & & \\
\hline T. dimidiatus & 26 & 1.000 & $<0.000001$ & 1.000 & $<0.000001$ & Ecoregions & Ecoregions \\
\hline T. eliasi & 7 & 0.428 & $<0.000001$ & 1.000 & $<0.000001$ & Altitude & Altitude \\
\hline T. gratiosus bonafidei & 5 & 0.200 & 0.004200 & 1.000 & 0.000004 & PWQ & Ecoregions \\
\hline T. iheringi & 15 & 0.867 & $<0.000001$ & 0.867 & $<0.000001$ & Ecoregions & Ecoregions \\
\hline T. panema & 16 & 0.938 & $<0.000001$ & 0.938 & $<0.000001$ & Ecoregions & Ecoregions \\
\hline T. setosus elegans & 12 & 0.833 & $<0.000001$ & 0.917 & $<0.000001$ & Ecoregions & Ecoregions \\
\hline T. setosus setosus & 16 & 0.938 & $<0.000001$ & 0.938 & $<0.000001$ & Ecoregions & Ecoregions \\
\hline
\end{tabular}

Table III. The occurrence of six Trinomys species by ecoregions. Ecoregions are according to Otson et al. 2001.

\begin{tabular}{|c|c|c|c|c|c|c|c|}
\hline Ecoregions & T. dimidiatus & T. eliasi & T. g. bonafidei & T. iheringi & T. panema & T. s. elegans & T. s. setosus \\
\hline Alto Paraná Atlantic Forest & 0 & 1 & 3 & 1 & 1 & 0 & 0 \\
\hline Atlantic Coastal Restingas & 0 & 1 & 0 & 0 & 0 & 0 & 0 \\
\hline Bahia Coastal Forest & 0 & 0 & 0 & 0 & 4 & 0 & 8 \\
\hline Bahia Interior Forest & 0 & 0 & 0 & 0 & 9 & 10 & 5 \\
\hline Campos Rupestres Montane Savanna & 0 & 0 & 1 & 0 & 1 & 0 & 0 \\
\hline Cerrado & 0 & 0 & 0 & 0 & 1 & 2 & 1 \\
\hline Pernambuco Interior Forest & 0 & 0 & 0 & 0 & 0 & 0 & 2 \\
\hline Serra do Mar Coastal Forest & 25 & 5 & 1 & 13 & 0 & 0 & 0 \\
\hline Southern Atlantic Mangroves & 1 & 0 & 0 & 1 & 0 & 0 & 0 \\
\hline
\end{tabular}

Trinomys dimidiatus showed a potential distribution ranging from São Paulo to the north of Rio de Janeiro, very similar to the known distribution (Fig. 3). Trinomys eliasi also showed a potential distribution very similar to the known distribution, being restricted to the coastal area of Rio de Janeiro and to a small portion of the coast of Espírito Santo (Fig. 4). Trinomys gratiosus bonafidei presented a large and disjoint potential distribution ranging from the central portion of Minas Gerais to the coast of Santa Catarina, including Rio de Janeiro, São Paulo and Paraná. (Fig. 5). Trinomys iheringi presented a potential distribution restricted to the coastal region, from Rio de Janeiro to Santa Catarina (Fig. 6). Trinomys panema has a broad distri- 


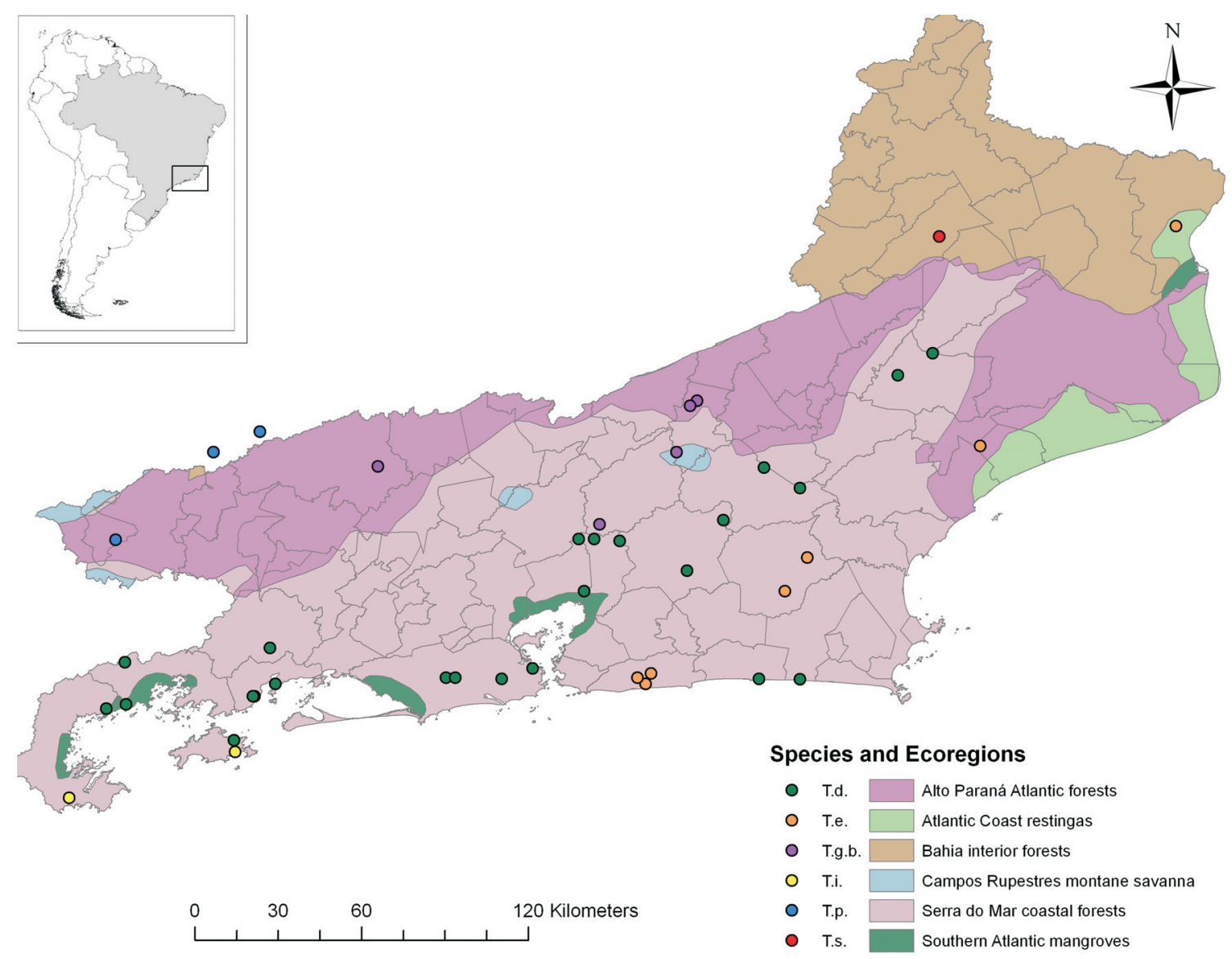

Figure 2. Map of Rio de Janeiro State, divided in ecoregions, showing the records from the literature and the present study for the six Trinomys species.

bution and presented a very large potential distribution occupying completely the Rio de Janeiro and Espírito Santo, a great portion of São Paulo and Minas Gerais and a portion of south Bahia. (Fig. 7). Trinomys setosus elegans appears to be restricted to Minas Gerais, presenting only small bordering areas in Rio de Janeiro and Bahia (Fig. 8). Trinomys setosus setosus presented the broadest potential distribution among all species analyzed in this study. The potential distribution shows a disjoint distribution that ranges over several states in the coast and central portion of the country (Fig. 9).

\section{DISCUSSION}

Species of Trinomys are common in faunal inventory and in studies carried out in the Atlantic Forest (e.g. Pereira et al. 2001, GeIse et al. 2004, VAZ 2005). However, in three sampled localities in Rio de Janeiro, we did not capture Trinomys (MSJ, FM and REGUA). MSJ is located in coastal plain of Rio de Janeiro, in a region that is subject to considerable anthropic disturbance. The small mammal richness was very low in the area (only four species), and the absence of Trinomys may not be due to sampling problems, but to the fact that MSJ is very degraded and isolated from other forest fragments, being surrounded by pasture. It is possible, that the Trinomys population in the area could have become locally extinct.

Many species were captured in FM, but most of them are recognized as typical of high altitudes. This area is located from 1220 to $1775 \mathrm{~m}$ and Trinomys species do not seem to occur in localities above $1300 \mathrm{~m}$. Bonvicino et al. (1997) and GeIse et al. (2004) captured, respectively, T. gratiosus, in the Caparaó National Park and T. panema (= T. gratiosus in GeIse et al. 2004) in the Maciço do Itatiaia, below $1200 \mathrm{~m}$. Species from the genus probably do not occur in areas above the Montane region (from 500 to $1499 \mathrm{~m}$ ) (sensu URURAHY et al. 1983).

The lack of Trinomys spp. in REGUA (altitudes varying from 175 to $325 \mathrm{~m}$ a.s.l.) was unexpected. Specimens of T. dimidiatus were captured in adjacent areas, as the EEEP and Vale da Pedra Branca Farm (Fig. 1), both localities at Serra dos Órgãos and in similar altitudes, suggesting that this species should occur in REGUA. Trinomys gratiosus bonafidei, until now, was known only from its type locality, in Boa Fé Farm, in Teresópolis Municipal- 

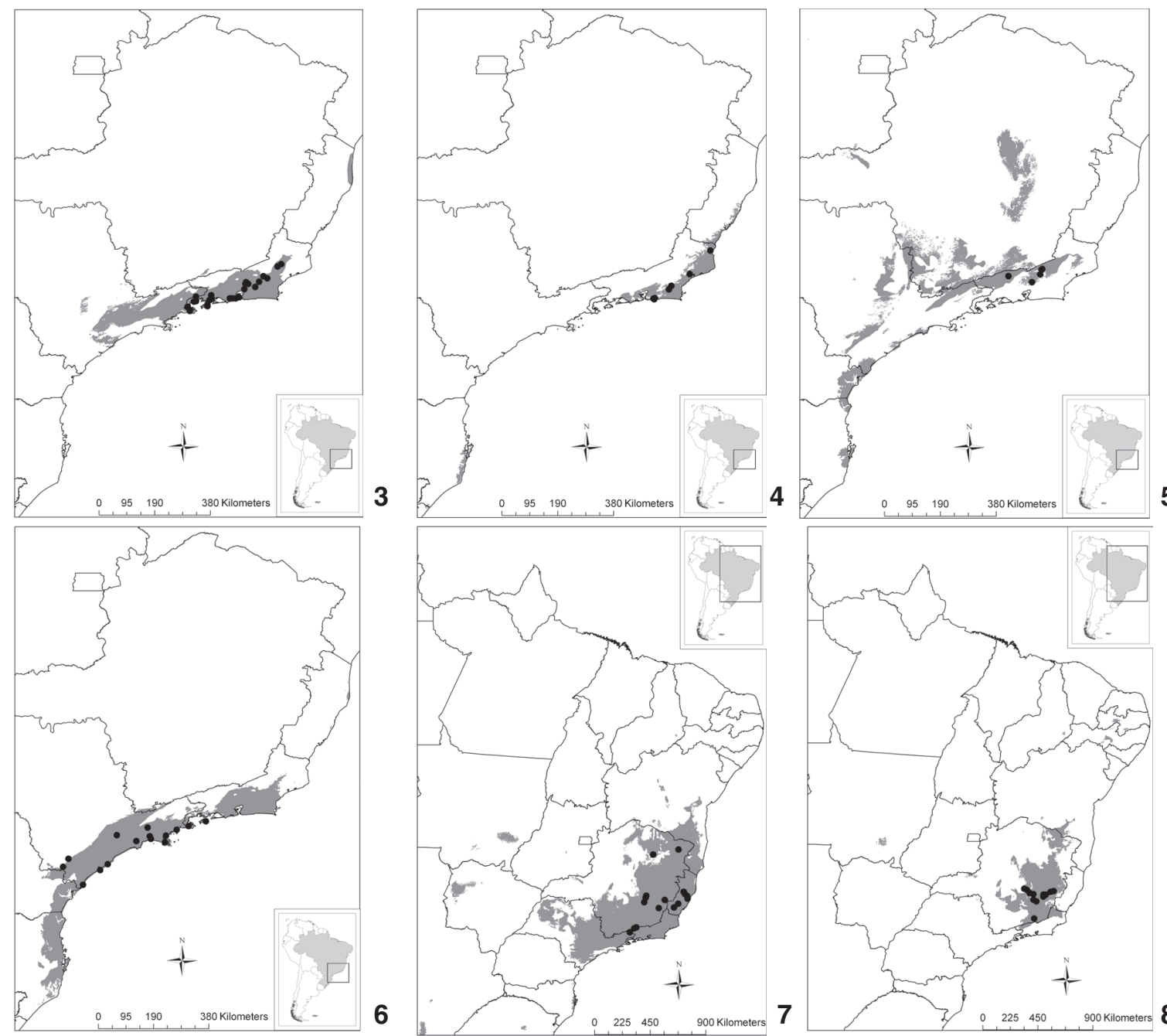

5
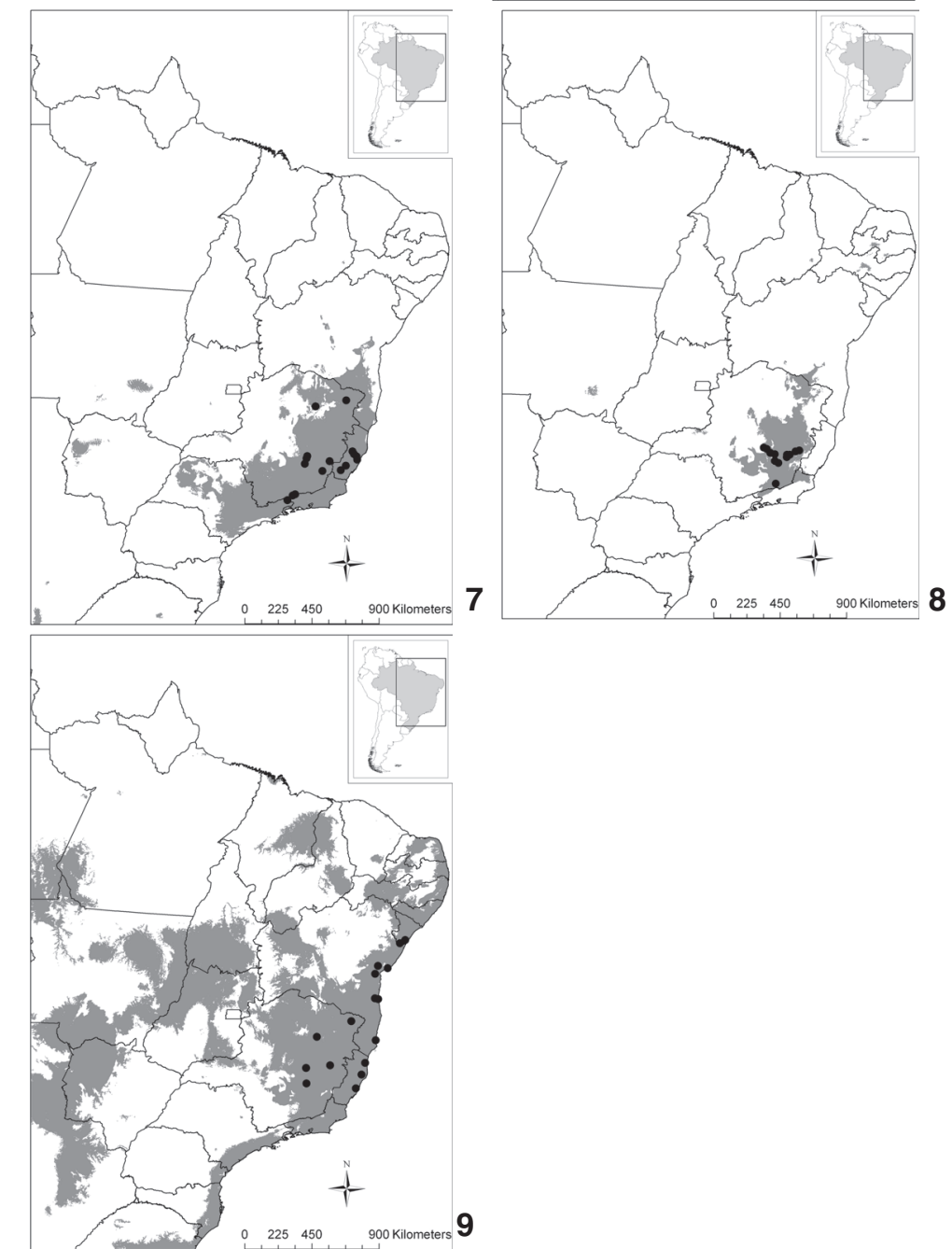

Figures 2-9. Potential distribution of Trinomys species in the Brazilian territory: (3) T. dimidiatus; (4) T. eliasi; (5) T. gratiosus bonafidei; (6) T. iheringi; (7) T. panema; (8) T. setosus elegans; (9) T. setosus setosus. 
ity, and adjacent areas in Serra dos Órgãos, a region dominated by Evergreen Forest. The new record of this species in Serra da Concórdia extends its distribution in $100 \mathrm{~km}$, in a straight line to northwest and into a region of Semidecidual Seasonal Forest. Trinomys gratiosus bonafidei is now known from three different ecoregions: Alto Paraná Atlantic Forest, Campos Rupestres Montane Savanna and Serra do Mar Coastal Forest.

Trinomys setosus was not known in Rio de Janeiro, with its southernmost record located in Juiz de Fora, Minas Gerais $\left(21^{\circ} 45^{\prime} \mathrm{S} 43^{\circ} 20^{\prime} \mathrm{W}\right)$. Until the present time, Trinomys setosus occurred from Sergipe to Minas Gerais, including Bahia and Espírito Santo (Lara et al. 2002). Trinomys setosus has three subspecies with disjoint distributions, T. s. elegans, T. s. denigratus and T. s. setosus, the latter being restricted to Minas Gerais (LARA et al. 2002). However, it was not possible to identify the specimens captured in Cambuci in a subspecific level. When considered only in at the species level, the distribution of T. setosus was extended in $150 \mathrm{~km}$ east from Juiz de Fora, into the Rio de Janeiro.

Trinomys eliasi and T. gratiosus bonafidei showed low rates of success ( 0.428 and 0.200 , respectively) suggesting that the models were not efficient. However, the potential distribution of both species is congruent with the altitudinal and ecoregion distributions, respectively. The potential distribution of Trinomys eliasi followed the coast up to south Espírito Santo in Atlantic Forest Restinga, Bahia Coastal Forest and Southern Atlantic Mangroves ecoregions in low altitudes. Restricted to the coast, T. eliasi may be more susceptible to threats due to the vulnerability of the region to human disturbance, especially real estate developments. Habitats of restinga, for example, have considerable biological relevance, yet they are subject to intense degradation (Rocha et al. 2005).

Trinomys g. bonafidei presented a potential distribution mainly in the Alto Paraná Atlantic Forest ecoregion, where the species was recorded. Although it is endemic to Rio de Janeiro, the potential distribution of $T$. $g$. bonafidei suggests that this species may also occur in northeast São Paulo and south Minas Gerais. The absence of the species in these localities may reflect small sample effort, as these areas are more distant from the major urban centers.

The potential distributions of $T$. dimidiatus and T. iheringi overlapped considerably. Both potential distributions followed the Serra do Mar Coastal forest ecoregion, with the southern range of $T$. iheringi reaching Santa Catarina. However, sympatry is observed in the border of Rio de Janeiro and São Paulo in the coast. The inferred potential distributions were similar to those suggested by LARA et al. (2002).

The potential distribution of Trinomys setosus elegans seems to be restricted to Bahia Interior Forest ecoregion. The specimen collected by us in Esmeralda Farm, in the municipality of Cambuci, can belong to this subspecies, since the municipality is located in the same ecoregion. Although T. panema was the species occurring in most ecoregions (5, see Tab. III), the potential distribution was restricted mainly to the south- eastern region (São Paulo, Rio de Janeiro, Espírito Santo and Minas Gerais) and a small portion of Bahia. On the other hand, T. s. setosus, recorded for four ecoregions, showed the broadest studied distribution, including states from north to south and east to west of Brazil. This distribution is probably overestimated and more records are necessary to better evaluate its distribution. Trinomys panema and T. s. elegans seem to overlap in their potential distributions with T. moojeni (LARA et al. 2002).

These new records show the importance of a greater research effort in areas that have not been well studied and in small remaining fragments. We still were not able to define the species boundaries of Trinomys spp. due to the number of records available. But the potential distribution estimated in this study can be used as a guideline to fill these information gaps, defining future study areas. The efforts must encompass as many ecoregions as possible, since this variable had a great effect in the distribution of the Trinomys species.

\section{ACKNOWLEDGMENTS}

We would like to thank Leila M. Pessôa, William C. Tavares, and Gilson E.Iack-Ximenes, for the help in identifying the specimens and João Oliveira and Stella Franco, from Museu Nacional, for their support. The team of Laboratório de Ecologia de Pequenos Mamíferos, M.C. Enrici, W.S. Souza, P.M. Ferreira, N. Ardente, B.C. Pereira, J.L. Luz and I.C.M. Lessa helped us during the field work. We thank Donald Gettinger and two anonymous referees for their contribution in the text. This work was supported by the Critical Ecosystem Partnership Fund (CEPF) and by Aliança para Conservação da Mata Atlântica (Conservation International - Brazil and SOS Mata Atlântica). We thank Instituto Biomas for their support in the field work. NA and DSLR thanks FAPERJ, HA, FP and TJN thanks CNPq and TCM thanks CAPES for the scholarships. HGB thanks CNPq and Prociência/UERJ by the productivity grants.

\section{LITERATURE CITED}

Bergallo, H.G.; F. Martins-Hatano; D.S.L. Raíces; T.T.L. Ribeiro; A.G. Alves; J.L. Luz; R. Mangolin \& M.A.R. Mello. 2004. Os mamíferos da Restinga de Jurubatiba, p. 215-230. In: C.F.D. Rocha; F.A. Esteves \& F.R. Scarano (Eds). Pesquisas de longa duração na Restinga de Jurubatiba. Ecologia, História Natural e Conservação. São Carlos, Editora Rima, 374p.

Bittencourt, E.B. \& C.F.D. Rocha. 2003 Host-ectoparasite Specificity in a Small Mammal Community in an Area of Atlantic Rain Forest (Ilha Grande, RJ), Southeastern Brazil. Memórias do Instituto Oswaldo Cruz 98 (6): 793-798.

Bonvicino, C.R.; A. Langguth; S.M. Lindbergh \& A.C. de Paula. 1997. An elevational gradient study of small mammals at Caparaó National Park, South eastern Brazil. Mammalia 61 (4): 547-560.

Brito, D. \& M. De S.L. Figueiredo. 2003. Minimum viable population and conservation status of the Atlantic Forest spiny 
rat Trinomys eliasi. Biological Conservation 113: 153-158. CorrêA, M.M. de O.; M.O.G. Lopes; E.V.C. CÂmara; L.C. Oliveira \& L.M. PessôA. 2005. The karyotypes of Trinomys moojeni (Pessôa, Oliveira \& Reis, 1992) and Trinomys setosus elegans (Lund, 1841) (Rodentia, Echimyidae) from Minas Gerais, eastern Brazil. Arquivos do Museu Nacional 63 (1): 169-174.

Costa, M.B.; M.A. Santos; R.S. Alencar; A.C.R. Cozzolino; C.F.D. Rocha; H.G. Bergallo; M.A.S. Alves; M. Van Sluys; M.C. Uzeda; E.C. FIdAlgo; T.C.C. Costa. 2008. Conservação da Biodiversidade da Mata Atlântica do Estado do Rio de Janeiro: estado atual e propostas de estratégias e ações. Revista de Economia Fluminense 4: 22-25.

CunHA, A.A. \& H. RajÃo. 2007. Mamíferos Terrestres e Aves da Terra Indígena Sapukai (Aldeia Guarani do Bracui), Angra dos reis, Rj, Brasil. Boletim do Museu de Biologia Mello Leitão 21: 19-34.

EMmONs, L.H. \& F. FeER. 1997. Neotropical Rainforest mammals: a field guide. Chicago, University of Chicago Press, $2^{\text {nd }}$ ed., $\mathrm{XIII+281p.}$

EISENBERG, J.F. \& K.H. REDFORD. 1999. Mammals of the Neotropics: the Central Neotropics. Chicago, The University of Chicago Press, vol. 3, IX+609.

Fidalgo, E.C.C.; M.C. Uzeda; H.G. Bergallo \& T.C.C. da Costa, 2007. Remanescentes da Mata Atlântica no Estado do Rio de Janeiro: distribuição dos fragmentos e possibilidades de conexão. Florianópolis, Anais do XIII Simpósio Brasileiro de Sensoriamento Remoto, ISBN: 978-85-17-00031-7.

Fundação SOS Mata Atlântica. 2002. Atlas dos remanescentes florestais da Mata Atlântica; período 1995-2000: Relatório Final. São José dos Campos, Fundação SOS Mata Atlântica, Instituto Nacional de Pesquisas Espacias, 47p.

Geise, L.; L.G. Pereira; D.E.P. Bossi \& H.G. Bergallo. 2004. Pattern of elevational distribution and richness of non volant mammals in Itatiaia National Park and its surroundings, in southeastern Brazil. Brazilian Journal of Biology 64 (3B): 599-612.

Hijmans, R.J.; S.E. Cameron; J.L. Parra; P.G. Jones \& A. Jarvis. 2005. Very high resolution interpolated climate surfaces for global land areas. International Journal of Climatology 25 (15): 1965-1978.

Lara, M.C. \& J. L. Patton. 2000. Evolutionary diversification of spiny rats (genus Trinomys, Rodentia: Echyimidae) in the Atlantic Forest of Brazil. Zoological Journal of the Linnean Society 130: 661-686.

Lara, M.C.; J. L. Patton \& E. Hingst-Zaher. 2002. Trinomys mirapitanga, a new species of spiny rat (Rodentia: Echimyidae) from the Brazilian Atlantic Forest. Mammalian Biology 67: 233-242.

Medeiros, M.F.T.; V.S. da Fonseca \& R.H.P. Andreata. 2004. Plantas medicinais e seus usos pelos sitiantes da Reserva Rio das Pedras, Mangaratiba, RJ, Brasil. Acta Botânica Brasílica18 (2): 391-399.

Moojen, J. 1948. Speciation in the Brazilian spiny rats (Genus Proechimys, Family Echimyidae). University of Kansas
Publications 1: 301-406.

Olifiers, N.; A.A. Cunha; C.E.V. Grelle; C. Bonvicino; L. Geise; L.L.G. Pereira; M.V. Vieira; P. S. Dandrea; R. Cerqueira. 2007. Lista de espécies de pequenos mamíferos não-voadores do Parque Nacional da Serra dos Órgãos, p. 183-192. In: C. CRONEMBERger \& E.B. Viveiros de CASTRo (Eds). Ciência e Conservação na Serra dos Órgãos. Brasília, IBAMA, Centro Nacional de Informação, Tecnologias Ambientais e Editoração, 298p.

Oliveira, J.A. \& C.R. Bonvicino. 2006. Ordem Rodentia, p. 347406. In: N.R. Reis; A.L. Peracchi; W.A. Pedro \& I.P. Lima (Eds). Mamíferos do Brasil. Londrina, EDIFURB, 437p.

Olson, D.M.; E. Dinerstein; E.D. WikRAMAnayaKe; N.D. BuRgess; G.V.N. Powell; E.C. Underwood; J.A. D'Amico; I. Itoua; H.E. Strand \& J.C. Morrison. 2001. Terrestrial Ecoregions of the World: A New Map of Life on Earth. BioScience 51 (11): 933-938.

Pearson, R.G.; C.J. Raxworthy; M. Nakamura \& A. Townsend Peterson. 2007. Predicting species distributions from small numbers of occurrence records: a test case using cryptic geckos in Madagascar. Journal of Biogeography 34 (1): 102-117.

Pereira, L.G.; S.E.M.Torres; H. da Silva \& L. Geise. 2001. Nonvolant mammals of Ilha Grande and adjacent areas in southern Rio de Janeiro State, Brazil. Boletim do Museu Nacional, Nova Série, 459: 1-15.

PessôA, L.M.; S.F. Reis; M. Passamani \& S. Mendes. 1993. Notes on the distribution of Proechimys iheringi denigratus, Proechimys iheringi paratus and Proechimys iheringi gratiosus in eastern Brazil (Rodentia: Echimyidae). Zoologischer Anzeiger 231 (1-2): 21-23.

PessôA, L.M. \& S.F. ReIs. 1993. A new subspecies of Proechimys iheringi Thomas (Rodentia: Echyimidae) from the State of Rio de Janeiro, Brazil. Zeitschrift für Saugetierkunde 58: 181-190.

PessôA, L.M. \& S.F. ReIs.1996. Proechimys iheringi. Mammalian Species 536: 1-4.

Phillips, S.J.; R.P. Anderson \& R.E. Schapire. 2006. Maximum entropy modeling of species geographic distributions. Ecological Modelling 190: 231-259.

Philuips, S.J. \& M. Dudik. 2008. Modeling of species distributions with Maxent: new extensions and a comprehensive evaluation. Ecography 31 (2): 161-175.

Rocha, C.F.D.; H.G. Bergallo; J.P. Pombal Jr; L. Geise; M. Van Sluys; R. Fernandes \& U. Caramaschi. 2004. Fauna de anfíbios, répteis e mamíferos do Estado do Rio de Janeiro, sudeste do Brasil. Publicações avulsas do Museu Nacional 104: 1-24.

Rocha, C.F.D.; M. Van Sluys; H.G. Bergallo \& M.A.S. Alves. 2005. Endemic and Threatened Tetrapods in the Restingas of the Biodiversity Corridors of Serra do Mar and of the Central da Mata Atlântica in Eastern Brazil. Brazilian Journal of Biology 65 (1): 159-168.

Saraça, C.E.; I.S. Rahy; M.A. SAntos; M.B. Costa \& W.R. Peres. 2007. A propósito de uma nova regionalização para o Estado do Rio de Janeiro. Revista de Economia Fluminense 6: 18-27.

Ururahy, J.C.C.; J.E.R. Collares,; M.M. Santos \& R.A.A. Barreto. 1983. Geologia, geomorfologia, pedologia, vegetação e uso 
potencial da terra, p. 23-24. In: Projeto RADAMBRASIL, As regiões fitoecológicas, sua natureza e seus recursos econômicos. Estudo fitogeográfico. Rio de Janeiro, Projeto RADAMBRASIL, vol. 4, 780p.

VAZ, V.C.; P.S. D'ANDREA; A.M. JANSEN. 2007. Effects of habitat fragmentation on wild mammal infection by Trypanosoma cruzi. Parasitology 134: 1785-1793.
VAZ, S.M. 2005. Mamíferos coletados em Pedra Branca, Município de Paraty, Rio de Janeiro, Brasil. Revista Brasileira de Zoologia 22 (4): 1164-1169.

Viveiros de Castro, E.B. \& F. A. S Fernandez. 2004. Determinants of differential extinction vulnerabilities of small mammals in Atlantic Forest fragments in Brazil. Biological Conservation 119 (1): 73-80.

Appendix 1. Characterization of the surveyed areas.

1) Paraíso State Ecological Station - EEEP $\left(22^{\circ} 26^{\prime} \mathrm{S}, 42^{\circ} 56^{\prime} \mathrm{W}\right)$, located between the municipalities of Guapimirim and Cachoeiras de Macacú, in the central portion of Rio de Janeiro State. The EEEP has an area of 4290 ha being covered by Atlantic Forest in different stages of conservation, with remnants of forests with low disturbance occurring in the least accessible areas, due to the terrain. The climate of the region is warm and humid and the annual rainfall of the area varies from 2000 to $2500 \mathrm{~mm}$; the average temperature is $24^{\circ} \mathrm{C}$. The vegetation is characterized by Evergreen Dense Forest. The altitude in EEEP varies between 60 and $1350 \mathrm{~m}$ a.s.l. The inventory was carried out in areas with altitudes between 20 and $340 \mathrm{~m}$, in September of 2004.

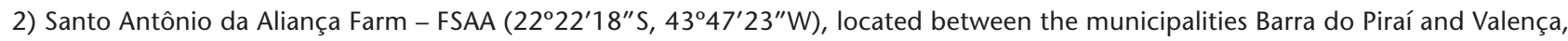
and including the Serra da Concórdia Wildlife Sanctuary. This locality has an area of 295 ha, of which 220 ha are a legal reserve, with altitudes between 600 and $925 \mathrm{~m}$ a.s.l. The average annual temperature is $20.4^{\circ} \mathrm{C}$, with maximum of $28.7^{\circ} \mathrm{C}$ and minimum of $10.8^{\circ} \mathrm{C}$. The annual precipitation is $1469 \mathrm{~mm}$. The vegetation is characterized by a Semidecidual Seasonal Forest with several stages of succession. The inventory of this area was carried out in April of 2005.

3) Rio das Pedras Ecological Reserve - RERP $\left(22^{\circ} 59^{\prime} \mathrm{S}, 44^{\circ} 05^{\prime} \mathrm{W}\right)$ is located in the municipality of Mangaratiba, in the west of the state of Rio de Janeiro, on the Atlantic side of the Serra do Mar, near Sepetiba Bay. The reserve area encompasses 1360 ha of Evergreen Dense Forest in several stages of succession. The altitude in the reserve varies between the sea level and $1100 \mathrm{~m}$, but the study was carried out from 25 to $700 \mathrm{~m}$. The average annual temperature is $22^{\circ} \mathrm{C}$, with maximum of $38^{\circ} \mathrm{C}$ and minimum of $12^{\circ} \mathrm{C}$. The highest rainfall rates occur between December and February (MedelRos et al. 2004). The inventory of this area was carried out in August of 2005.

4) Desengano State Park - PED $\left(21^{\circ} 52^{\prime} 43,2^{\prime \prime} S, 41^{\circ} 54^{\prime} 14,1^{\prime \prime} \mathrm{W}\right)$ is located in the municipalities of Santa Maria Madalena, São Fidélis and Campos dos Goytacazes. The park, which is considered the last continuous remnant of Atlantic Forest in the region, has a total area of 23,000 ha. The altitude varies between 800 and $1700 \mathrm{~m}$ a.s.l. The vegetation is composed by Evergreen Dense Forest. The annual temperature varies between $12^{\circ}$ e $30^{\circ} \mathrm{C}$, with average annual temperature $16.7^{\circ} \mathrm{C}$ and annual precipitation $1471 \mathrm{~mm}$. This study was carried out in a region called Morumbeca, in Santa Maria Madalena Municipality, with altitude between 1060 and $1425 \mathrm{~m}$, in May of 2006.

5) Vale da Pedra Branca Farm - FVPB (22 $25^{\prime} 07,9^{\prime \prime}$ S, $\left.42^{\circ} 34^{\prime} 52,9^{\prime \prime} \mathrm{W}\right)$ is located in the municipality of Nova Friburgo, adjacent to Três Picos State Park. The locality has an area of 550 ha and is covered by well preserved Atlantic Forest. The area climate is hot and humid. The annual rainfall varies between 2000 and $2500 \mathrm{~mm}$ and the annual average temperature is $24^{\circ} \mathrm{C}$ with maximum of $27.7^{\circ} \mathrm{C}$ and minimum of $10.5^{\circ} \mathrm{C}$. The altitude in the area varies from 500 to $1600 \mathrm{~m}$ a.s.l., although the studied area comprises altitudes only from 500 to $850 \mathrm{~m}$. The vegetation in the area is mostly Evergreen Dense Forest. The study in this area was carried out in October of 2006.

6) Esmeralda Farm - FE ( $\left.21^{\circ} 29^{\prime} 03^{\prime \prime} S 41^{\circ} 52^{\prime} 21,8^{\prime \prime} \mathrm{W}\right)$, municipality of Cambuci, located north of Paraíba do Sul River. The vegetation of the area is composed by fragments of secondary forest, (Semidecidual Seasonal Forest), located mainly in the less accessible portions of the hills. The surroundings of the fragments show signs of human pressure, being commonly dominated by abandoned pastures and with the presence of the exotic grass, Brachiaria. The average annual temperature varies from $15^{\circ}$ to $35^{\circ} \mathrm{C}$ and the annual rainfall is $1276 \mathrm{~mm}$. The whole forest fragment has approximately 1000 ha, being the only one in the region with this extension (Fidalco et al. 2007), although the studied area was small (approximately 5 ha). The inventory of this area was carried out in August of 2006.

7) Guapiaçú Ecological Reserve - REGUA ( $\left.22^{\circ} 24^{\prime} \mathrm{S}, 42^{\circ} 44^{\prime} \mathrm{W}\right)$, located in the municipality of Cachoeiras de Macacú. The locality has an area of 2588 ha and is covered by Atlantic Forest in different stages of conservation with remnants of forests with low disturbance occurring in the less accessible areas, due to the relief. Along with State Park of Três Picos and National Park of Serra dos Órgãos, REGUA occupies a strategic location for conservation and protection of the hydrographic basin of Guanabara Bay. The climate is

Continue 
Appendix 1. Continued.

hot and humid with an annual rainfall ranging from 2000 to $2500 \mathrm{~mm}$ and an average temperature of $24^{\circ} \mathrm{C}$ with maximum of $28.9^{\circ} \mathrm{C}$ and minimum of $11.5^{\circ} \mathrm{C}$. The altitude varies from 80 to $1600 \mathrm{~m}$ a.s.l. although the study was carried out in areas between 80 and $400 \mathrm{~m}$ a.s.I., on the margins of Manuel Alexandre river. The vegetation in the study area is characterized by an Evergreen Forest. The inventory of this area was conducted in October of 2004.

8) Marimbondo Farm- FM (22 $21^{\prime} 47^{\prime \prime} S, 44^{\circ} 35^{\prime} 47,47^{\prime \prime}$ W), property of Agropecuária Santa Fé, part of the APA Serra da Mantiqueira (Environmental Protection Area), municipality of Itatiaia, in the northwestern part of the state. The farm, with an average altitude of $1549 \mathrm{~m}$, has an area of $34475 \mathrm{ha}$. The annual average temperature in the region is $14.9^{\circ} \mathrm{C}$, with maximum of $22.9^{\circ} \mathrm{C}$ and minimum of $3.7^{\circ} \mathrm{C}$. The annual rainfall is $1813 \mathrm{~mm}$. Our study was conducted in altitudes from 1200 to $1775 \mathrm{~m}$ in November of 2005. The vegetation of the area is characterized by Evergreen Mixed Forest. This area has experienced a great impact with human occupation and now is dominated by pasture and secondary vegetation that surrounds the preserved area.

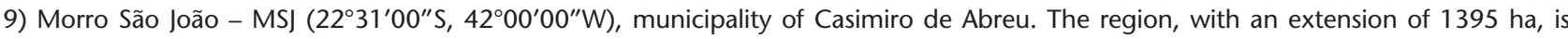
actually a hill of volcanic origin with 640 ha covered by secondary forest and around $670 \mathrm{~m}$ of altitude. The annual average temperature is $23^{\circ} \mathrm{C}$, with maximum of $29.7^{\circ} \mathrm{C}$ and minimum of $15.9^{\circ} \mathrm{C}$, and the annual rainfall is $1058 \mathrm{~mm}$. The locality is within an area of Evergreen Dense Forest and surrounded by pastures and farmlands. The inventory of this area was conducted in June of 2005.

Appendix 2. Minimum (Min), maximum (Max) and mean of climatic variables and altitude for Trinomys species. (AMT) Annual Mean Temperature, (MDR) Mean Diurnal Range, (ISO) Isothermality, (TES) Temperature Seasonality, (MTWM) Maximum Temperature of Warmest Month, (MTCM) Minimum Temperature of Coldest Month, (ATR) Annual Temperature Range, (MTWE) Mean Temperature of Wettest Quarter, (MTDQ) Mean Temperature of Driest Quarter, (MTWA) Mean Temperature of Warmest Quarter, (MTCO) Mean Temperature of Coldest Quarter, (ANP) Annual Precipitation, (PWM) Precipitation of Wettest Month, (PDM) Precipitation of Driest Month, (PRS) Precipitation Seasonality, (PWE) Precipitation of Wettest Quarter, (PDQ) Precipitation of Driest Quarter, (PWQ) Precipitation of Warmest Quarter, (PCQ) Precipitation of Coldest Quarter. Temperature measures are in Celsius $\left({ }^{\circ} \mathrm{C}\right)$ and Precipitation measures are in millimeters.

\begin{tabular}{|c|c|c|c|c|c|c|c|c|c|c|c|c|}
\hline \multirow{2}{*}{ Variables } & \multicolumn{3}{|c|}{ T. dimidiatus } & \multicolumn{3}{|c|}{ T. eliasi } & \multicolumn{3}{|c|}{ T. gratiosus bonafidei } & \multicolumn{3}{|c|}{ T. iheringi } \\
\hline & Min & Max & Mean & Min & Max & Mean & Min & Max & Mean & Min & Max & Mean \\
\hline AMT & 15.40 & 23.70 & 20.64 & 22.90 & 23.30 & 23.17 & 18.20 & 21.80 & 19.80 & 16.60 & 23.70 & 20.41 \\
\hline MDR & 7.40 & 11.80 & 9.75 & 8.00 & 9.10 & 8.44 & 10.00 & 11.80 & 10.90 & 7.40 & 10.50 & 9.06 \\
\hline ISSO & 5.50 & 6.20 & 5.82 & 5.50 & 6.00 & 5.69 & 5.70 & 6.10 & 5.98 & 4.90 & 5.90 & 5.43 \\
\hline TES & 191.80 & 232.90 & 211.61 & 179.70 & 207.90 & 197.59 & 214.00 & 224.10 & 220.10 & 206.50 & 312.70 & 243.73 \\
\hline MTWM & 23.50 & 31.10 & 28.66 & 30.00 & 30.70 & 30.39 & 26.70 & 30.90 & 28.44 & 23.90 & 30.90 & 28.12 \\
\hline MTCM & 4.60 & 16.80 & 11.90 & 14.60 & 16.20 & 15.70 & 9.30 & 11.80 & 10.36 & 7.30 & 15.40 & 11.61 \\
\hline ATR & 13.20 & 19.40 & 16.55 & 14.10 & 15.70 & 14.69 & 17.40 & 19.10 & 18.08 & 14.30 & 19.20 & 16.51 \\
\hline MTWE & 18.00 & 26.10 & 23.11 & 24.40 & 25.80 & 25.10 & 20.60 & 24.40 & 22.36 & 19.20 & 26.30 & 23.37 \\
\hline MTDQ & 12.40 & 21.30 & 17.90 & 20.30 & 20.80 & 20.69 & 15.50 & 18.80 & 16.94 & 13.40 & 20.70 & 17.29 \\
\hline MTWA & 18.10 & 26.40 & 23.38 & 25.40 & 26.20 & 25.80 & 20.80 & 24.60 & 22.54 & 19.50 & 26.50 & 23.49 \\
\hline MTCO & 12.40 & 21.30 & 17.81 & 20.30 & 20.80 & 20.69 & 15.30 & 18.80 & 16.88 & 13.40 & 20.70 & 17.22 \\
\hline ANP & 1203.00 & 1986.00 & 1528.78 & 1005.00 & 1192.00 & 1131.29 & 1406.00 & 1724.00 & 1512.40 & 1334.00 & 2946.00 & 1960.67 \\
\hline PWM & 147.00 & 305.00 & 234.89 & 148.00 & 181.00 & 160.43 & 269.00 & 305.00 & 281.20 & 199.00 & 359.00 & 269.93 \\
\hline PDM & 20.00 & 69.00 & 41.63 & 26.00 & 50.00 & 40.43 & 15.00 & 40.00 & 24.20 & 29.00 & 123.00 & 70.27 \\
\hline PRS & 35.00 & 69.00 & 52.93 & 36.00 & 50.00 & 42.57 & 62.00 & 73.00 & 69.80 & 36.00 & 61.00 & 43.87 \\
\hline PWE & 439.00 & 816.00 & 654.04 & 414.00 & 475.00 & 433.57 & 696.00 & 797.00 & 735.20 & 569.00 & 1054.00 & 773.13 \\
\hline PDQ & 81.00 & 212.00 & 138.30 & 92.00 & 152.00 & 127.14 & 58.00 & 136.00 & 85.80 & 111.00 & 391.00 & 238.20 \\
\hline PWQ & 439.00 & 783.00 & 604.70 & 316.00 & 411.00 & 383.14 & 596.00 & 706.00 & 647.40 & 567.00 & 1030.00 & 757.13 \\
\hline PCQ & 90.00 & 212.00 & 142.37 & 92.00 & 152.00 & 127.14 & 58.00 & 136.00 & 93.80 & 111.00 & 391.00 & 240.20 \\
\hline Altitude & 5.00 & 1311.00 & 430.67 & 0.00 & 41.00 & 15.71 & 369.00 & 963.00 & 683.60 & 2.00 & 914.00 & 374.40 \\
\hline
\end{tabular}


Appendix 2. Continued.

\begin{tabular}{|c|c|c|c|c|c|c|c|c|c|}
\hline \multirow{2}{*}{ Variables } & \multicolumn{3}{|c|}{ T. panema } & \multicolumn{3}{|c|}{ T. setosus elegans } & \multicolumn{3}{|c|}{ T. setosus setosus } \\
\hline & Min & Max & Mean & Min & Max & Mean & Min & $\operatorname{Max}$ & Mean \\
\hline AMT & 17.10 & 24.90 & 21.51 & 19.70 & 23.30 & 21.35 & 20.40 & 25.10 & 23.69 \\
\hline MDR & 8.50 & 13.00 & 11.26 & 10.20 & 12.50 & 11.76 & 6.30 & 12.90 & 9.03 \\
\hline ISSO & 6.10 & 7.00 & 6.38 & 6.10 & 6.70 & 6.39 & 6.00 & 7.00 & 6.39 \\
\hline TES & 163.00 & 224.40 & 190.87 & 165.70 & 217.00 & 196.44 & 92.60 & 203.60 & 151.37 \\
\hline MTWM & 25.20 & 32.70 & 29.64 & 27.50 & 32.10 & 29.62 & 28.50 & 32.90 & 30.52 \\
\hline МТСM & 7.40 & 18.00 & 12.12 & 9.70 & 13.10 & 11.32 & 10.00 & 20.30 & 16.55 \\
\hline ATR & 13.90 & 20.00 & 17.53 & 16.70 & 19.10 & 18.30 & 10.00 & 19.70 & 13.97 \\
\hline MTWE & 18.50 & 26.30 & 23.21 & 21.20 & 25.00 & 23.06 & 22.00 & 26.50 & 24.33 \\
\hline MTDQ & 15.10 & 22.70 & 18.93 & 17.00 & 20.50 & 18.75 & 17.60 & 26.20 & 22.81 \\
\hline MTWA & 19.10 & 27.10 & 23.72 & 21.70 & 25.60 & 23.54 & 22.60 & 27.00 & 25.43 \\
\hline MTCO & 14.70 & 22.70 & 18.87 & 16.90 & 20.50 & 18.58 & 17.60 & 23.40 & 21.56 \\
\hline ANP & 845.00 & 1560.00 & 1263.75 & 1116.00 & 1523.00 & 1280.50 & 845.00 & 1840.00 & 1340.25 \\
\hline PWM & 182.00 & 297.00 & 233.56 & 207.00 & 324.00 & 257.58 & 140.00 & 410.00 & 214.50 \\
\hline PDM & 5.00 & 41.00 & 21.13 & 6.00 & 19.00 & 11.92 & 6.00 & 123.00 & 49.00 \\
\hline PRS & 49.00 & 91.00 & 70.19 & 75.00 & 90.00 & 81.33 & 13.00 & 90.00 & 50.69 \\
\hline PWE & 466.00 & 795.00 & 641.00 & 611.00 & 824.00 & 700.58 & 326.00 & 948.00 & 564.69 \\
\hline PDQ & 18.00 & 149.00 & 77.56 & 25.00 & 65.00 & 41.67 & 21.00 & 379.00 & 167.75 \\
\hline PWQ & 289.00 & 716.00 & 486.81 & 442.00 & 685.00 & 527.67 & 182.00 & 640.00 & 369.81 \\
\hline PCQ & 18.00 & 156.00 & 80.69 & 35.00 & 87.00 & 52.83 & 29.00 & 552.00 & 262.38 \\
\hline Altitude & 13.00 & 1282.00 & 557.81 & 280.00 & 978.00 & 633.42 & 2.00 & 827.00 & 218.88 \\
\hline
\end{tabular}

Submitted: 12.III.2008; Accepted: 15.VI.2009.

Editorial responsibility: Luciano M. Verdade 